\title{
Displacement and Deplorable Living Conditions of Slum Dwellers: With Special Reference to Sylhet City
}

\author{
Md. Arif Uddin Khan ${ }^{1 *}$, Md. Akter Hossen ${ }^{1}$, Zakia Sharmin $^{1}$, \\ Tania Jannatul Kubra ${ }^{2}$ \\ ${ }^{1}$ Lecturer, Department of Sociology, Faculty of Social Science, University of Chittagong, Chittagong , \\ Bangladesh \\ ${ }^{2}$ Department of Sociology, Shahjalal University of Science and Technology, Sylhet, Bangladesh \\ *E-mail address: aukbabu@gmail.com
}

\begin{abstract}
Environmental displacement has already become extreme in geographically and environmentally vulnerable areas in Bangladesh. Thus, climate induced migration to big cities is getting spontaneous over the last few decades. Increasing numbers of slums represent a major challenge to development. Displaced people living in urban slums are in search of better and secure life. But urban slums located mostly in low lying environmentally hazardous area coupled with inadequate facilities like food, shelter, sanitation, high rates of malnutrition, density of population, communicable diseases, exposure to violence, health care make their life even worse. In other words it refers to informal areas suffering from problems of accessibility, narrow streets, the absence of vacant land and open spaces, very high residential densities, insufficient infrastructure and services. The study is fully based on primary data that followed stratified sampling method with triangulation research design and reviewing some related literatures from past research reports. This paper examines that exploration of living conditions of slum dwellers, it is seen that the sketch of their social life is very different, deplorable, unorganized, poor health status, using different kinds of family planning methods, lack of proper water supply and sanitation, low income group with inadequate education, leading unhealthy environment, to enhanced poverty, under nutrition of Bangladeshi's inhabitants those are engaged in various sectors of economical activities. Their present scenario of social life is very pathetic and miserable because of having been deprived from education, employment and other basic facilities of human life and as a result they are being regarded as a reluctant Dwellers. They are far from touch of modernization, fully separated and alienated from the mainstream of society.
\end{abstract}

Keywords: Displacement; Deplorable Condition; Slums; Environment; Slum Dwellers; Migration; Health

\section{INTRODUCTION}

Bangladesh is one of the world's most densely populated country and has also faced rapid population growth throughout the last century although the population growth rate has somewhat decreased to a moderate level in recent times. The country is going to witness a rapid spread of urbanization over the next decade. According to an estimate, by 2020, nearly every other man, woman and child will live in an urban area (World Bank ed., Bangladesh 2020 ). Unless this spread is effectively managed, the frenzied conditions and accompanying ills like pollution, joblessness and exacerbation of criminal activities is likely to multiply. According to Global Monitoring Report, the 2011 interim report of MDGs (World Bank, 2011), the urban poor in developing countries has decreased from 39 to 33 percent over the past ten years, however, absolute numbers of the urban poor is on the rise because of the increase of total world population. Slum dwellers in developing countries had increased from 657 million (1990) to 767 million (2000), and are estimated to be 828 million in 2011. 
Environmental displacement has already become intense in geographically and environmentally vulnerable areas in Bangladesh. Thus, climate induced migration to big cities is getting spontaneous over the last few decades. For instance, frequent exposure to natural disasters makes coastal people often bound to migrate in search of secure lives and livelihoods. Therefore, increased slum settlements in urban area which indicate physical manifestation of growing urban poverty. Slums are supposed to be potential target for the habitation of displaced people. But planned migration of displaced people in urban slums is yet to consider reducing their vulnerabilities. Urban poverty will increase if environmentally displaced people keep moving to city, while slum is their potential target for habitation. By analyzing population displacement in major natural events like flood and cyclone over 40 years, it has been found that on an average 25\% (39 million) and 2\% (3 million) populations in each major flood and cyclone are displaced. As coastal people constitute $28 \%$ of total populations, about 43 million people from coastal area will be dislocated if $88 \mathrm{~cm}$ sea level rises and proper adaptation measures are not taken to contain people in their own land. Though, frequency of one or more severe disasters in a year has already been experienced in Bangladesh like the year 2007 (Cyclone Sidr and flood) and 2009 (Cyclone Aila and Cyclone Bijli). Friedman, 2009 writes in "A city exploding with climate migrants" that about 500,000 people move to capital city. According to International Organization for Migration (IOM), about $70 \%$ of slum dwellers in Dhaka experienced some kind of environmental shocks. Several surveys on slum growth in Dhaka, conducted by Centre for Urban Studies (CUS) recorded slum populations 275,000 in $1974,718,143$ (2,156 slums) in 1991, 1.5 million (3007 slums) in 1996 and 3.4 million (4,966 slums) in 2005 (CUS, 2005). Living conditions for the vast majority of slum dwellers are deplorable, with high rates of malnutrition, communicable diseases, and exposure to violence. In other words it refers to informal areas suffering from problems of accessibility, narrow streets, the absence of vacant land and open spaces, very high residential densities, and insufficient infrastructure and services . It also shows the actual livelihood of slum dwellers. The overall urban housing quality in terms of residential density, occupancy ratio and structural conditions has all assumed critical situations in Bangladesh (Islam, 1996a). According to the census of slum area and floating population in Bangladesh, approximately 69 percent of the slum houses are made of poor construction materials (BBS, 1999). The health condition in the poor communities in the Third World cities is alarming as thousands of children still die every day from preventable disease related to the inadequate provision of water and sanitation (Bartlett, 2003). Few studies have been done on urban environmental health situation in the informal settlements (Salahuddin and Islam, 1982, Hussain, Ali and Kvale, 1999). The growing disparity in living standards in urban between the slum dwellers on one side and well-to-do urban elites on the other may lead to increased social and political instability. However, with a proper strategy for growth and employment, this can give rise for job creation in the non-farm sector and thus absorb surplus labor force generating in the agricultural sector. urban population is growing at an even faster rate of 4.9 percent, due to urban migration and the territorial expansion of existing urban areas. The urban population increased 2.6 million from 1981 to 1991; it is estimated to have increased at an average of 5.4 per cent per annum. Currently, the urban population is 25 million over 20 percent of the national population (Bangladesh National Report, 1996). Global statistics indicate that half of the world's population live in urban areas and this figure is estimated to reach 4.7 billion in 2030 with an increasing decline in rural population (UN Commission on Human Settlement Programme (UNCHS), 2008; United Nation Population Fund (UNFPA), 2007). The increasing growth of urban population especially in developing countries consequentially leads to the growth of urban slums (UNCHS, 2003), as about 60 percent of residents of cities in the developing countries live in slums (UNCHS, 1986. According to available statistics, the number of landless people has increased by 22 percent over the last 35 years. For example, in 1972, only 28 percent of the country's population was landless. At 
present this figure is as high as 50 percent (The Daily Star, May 7, 2006). The latest figures indicate that about 4.5 million of total population of Bangladesh is completely landless (BBS, 2010). A huge numbers of this landless population migrate to cities in the hope of finding a job. The informal settlement such as slums and squatters are their ultimate destination where there is dearth of civic services. The increase in the percentage of population residing in urban areas is due to three important factors. The first factor is the rural-urban differential in the rates of natural increase. During 2001-2011, the percentage growth of population in rural and urban areas was to the order of 12 and 32 per cent respectively. The second factor is migration from rural to urban areas. The people are on constant move from backward areas to potential areas for better employment opportunities and better amenities and facilities (Rasool et al. 2012; Dyson 2011; Parkins 2010). The third reason is the reclassification of villages and towns. The number of towns have increased from 4,378 in 2001 to 7,935 in 2011 while the number of metropolitan cities having million plus population has increased from 35 in 2001 to 53 in 2011 (Census of India ). Urban slums are characterised by deplorable living conditions with poor land use planning, inadequate social services, coupled with high levels of communicable diseases, and exposure to fire outbreaks, Poor infrastructure and vulnerable to risk like natural disaster, environmental hazard and health risk (Agyarko-Oduro, 2009; Butala, VanRooyen \& Patel, 2010). Slums mainly provide informal labor market, regarded as by low wage, insecurity and uncertainty of working hour. Almost all new comers to the city join the informal sector. The main sectors are garment industry, rickshaw pulling, street vending, construction work and small business. Besides, they are living in such houses where ventilation, drinking water, electricity and sewerage facilities are absent and the create new problems like unemployment underemployment high incidence of crime, proliferation of shanty towns, sub-standard housing, transportation, pollution and service supply problems . As the World Bank (1994, P. 9) rightly recognized, "Poverty is not only a problem of low incomes; rather, it is multi-dimensional problem that includes low access to opportunities for developing human capital and to education which might relate to some key that may help to turn out the whole scenario. Slum improvement projects in many developing countries have been 'action oriented packages' focusing on poverty with increased donor support (Harpham $\&$ Stephens, 1992) without focusing on the sustainability of the urban environment. By the mid 1970s, however, many governments in developing countries admitted their inability to meet the housing needs of their populations especially the low income groups through government public housing schemes (Skinner, Taylor \& Wegehn, 1987). Some government organizations and NGO have been working for decades to improve the slum dwellers standard of living, but as a whole the results are minimal.

\section{Background of the study}

Slums may be defined as a "compact settlement with a collection of poorly built tenements, mostly of temporary nature, crowded together usually with inadequate sanitation and drinking water facilities in unhygienic conditions" (NSSO 2003). A slum, as defined by the United Nations agency UN-HABITAT, is a run-down area of a city characterized by substandard housing and squalor and lacking in tenure security. It can also be defined as a thickly populated, run-down, squalid part of a city, inhabited by poor people. The slum area (Improvement Clearance and Redevelopment Act, 1971) defined "as an area which is or may be a source of danger to health, safety or convenience of the public of the area or its neighbourhood by the region of the area having inadequate or no basic amenities or being insanitary, degraded place, overcrowded or otherwise or the buildings in any area used or intended to be used for human habitation which are in any respects unfit for the human habitation". Slum housing is defined as "households that lack decent water supply, adequate sanitation facilities, sufficient living area, decent structural quality and security of tenure" 
(UNHABITAT, 2003). The World Bank, in a survey report defined a "slum" as a residential area where more than three hundred people live in one acre of land. An average of more than three adults live in a single room, 46 per cent of these houses are one-roomed and the average size is 120 square feet Ventilation, drinking water, electricity and sewerage facilities are absent in these houses (Democracy Watch, 2002). Slums are addressed with different names in different parts of the world. In the United States the old ethnic slums are known as the "Kerry patch", the "Ghetto",":Little Italy" etc. In case of cities of Southeast Asia, slums are referred as "Indian quarter" in Rangoon, "Chinese quarter" in Singapore, "Samphonthawang" in Bangkok and "Kampong" in Indonesia. In India, slums have a variety of names. They are known as "Jhopadpatti" in Mumbai, "Jhuggi" in Delhi, "Bustee" in Kolkata, "Cheris" in Chennai and "Keris" in Bangaluru. Generally, the term slum has been explained in relation to poor housing conditions and environment (Hutchinson, 1997; UNCHS, 2002), inadequate access to basic social services (Abrams, 1966), lack of rights and tenure to land and property (Rangwala, 2002; Waugh, 1995), as well as the concentration of low income groups in cities or urban areas (Srinivas, 1991). Slum, according to Hutchinson (1997), is a densely populated urban environment which is in a bad state of repairs and has inadequate services including poor sanitation, poor supply of electricity and irregular water supply to support its inhabitants. Additionally, a slum is described as any human settlement which lacks anyone of the following indicators: access to water and sanitation; sufficient living area; housing with durable materials; non-hazardous location and tenure security (Turkstra \& Raithelhuber, 2004). Review of the definitions used by national and local governments, statistical offices, institutions involved in slum issues and public perceptions reveals the following attributes of slums - Lack of basic services, Substandard housing or illegal and inadequate building structures, Overcrowding and high density, Unhealthy living conditions and hazardous locations ,Insecure tenure; irregular or informal settlements , Poverty and social exclusion, Minimum settlement size . There are two kinds of slums: notified and non-notified. Areas notified as slums by the respective municipalities, corporations, local bodies or development authorities are treated as notified slums. A slum is considered as a non-notified slum if it has a compact area of at least 300 people or about $60-70$ households of poorly built congested tenements, in unhygienic environment usually with inadequate infrastructure and lacking in proper sanitary and drinking water facilities (Chandrasekhar 2006). These slums are inhabited by mainly temporary migrants, such as construction workers or other temporary workers, or new rural migrants who find it extremely difficult to get any formal housing within their paying capacity. Available literature demonstrates conclusively that slums result from interplay of causes and are characterised by rapid urbanisation due to rural-urban migration, urban poverty, inadequate urban housing development programmes, lack of enforcement of planning standards and regulations, and lack of repairs and maintenance (UNCHS, 2003; 1986). These causes have characterised the development of slums in many developing countries especially in Africa and Asia. From a global perspective, slums are categorized by overcrowding, marginalization, harmful environmental exposure, poverty, social disadvantage, insecurity, and lack of access to amenities all features that lead to decreased social and environmental sustainability, as well as increased risk and vulnerability (Pelling, 2003). Rapid rate of urbanisation resulting from rural-urban migration is a major contributing factor to slum development in developing countries. The UNCHS (2003) indicates that Bogotá has seen sustained, rapid demographic growth through waves of ruralurban migration in the wake of general impoverishment and violence. This situation has resulted in the rapid expansion of the urban perimeter through illegal subdivisions, occupation and the development of marginal areas by immigrants. The situation in the Greater Cairo Metropolitan Area in Egypt is similar with about 40 percent of rural-urban migrants who perceive the city as a place where opportunities abound (Jerome, 1990). This situation has caused a mismatch in housing supply and demand, resulting in increasing slum development. 
Another cause of the formation and existence of slums in developing countries is poverty (Hari, 2006). Poverty and housing deficit in rapidly growing cities are reasons for emergence of slums (World Bank, 2002). Urbanization in Bangladesh is caused by an unsustainable rural economy with extreme privilege slimming down among the majority marginalized peasantry and landless poor. For urban population growth, the number of slums and the people who dwell in them are rapidly increasing. The high rate of growth of slums and population in Bangladesh living in slums has serious economic, social, and public health consequences. The government of Bangladesh has a structured health and family planning service delivery system for the rural poor; it does not have any comparable infrastructure for the urban poor. In urban areas the informal sector is not yet fully urbanized, those who live in the slums are largely distressed migrants from rural areas, most of them live below the poverty line and maintain the outlook and values of their rural heritage and they do not have sufficient access to the education, employment, and health facilities of the formal sector to attain any higher standard of living. The health and nutritional status of the urban poor is even worse than that of the rural poor infant and maternal mortality rates are higher than the national rates. These factors are likely to adversely affect the contraceptive behaviour of those who live in the slums and these factors possibly also help to explain why urbanization has had little effect on the declining fertility in Bangladesh. However, very little is currently known about reproductive behaviour and family planning in the urban slums. On the other hand, slums are usually characterized by urban decay, high rates of poverty and unemployment. As indicated by Srinivas (1991), many slum dwellers employ themselves in the informal economy usually with low incomes. These include street vending, drug dealing, domestic work and other forms of home based economic activities. As a result, slums are identified as breeding grounds for social problems such as crime, drug addiction, alcoholism, high rates of mental illness and suicide. In many developing countries, slums are characterised by high rates of diseases due to insanitary conditions, malnutrition, and lack of basic health care services (Abrams, 1966). Socially, slum dwellers are largely poor migrants and economic adventurers from neighbouring villages or countries in search of better economic opportunities. For example, Waugh (1995) describes slums in Singapore as unplanned zone within the city providing shelter for immigrants from neighbouring Asian countries. Again, slums are identified with low incomes, absence of occupational skills and qualifications, and poor housing. Hari (2006) argues that the increasing trend of rural-urban migration is making poverty more urbanised, and this increases the risk of homelessness especially among slum dwellers in developing countries. Slum dwellers are often minority and voiceless groups in urban areas. The interactions between poverty and insecure tenure in urban slums contribute to further deterioration of the economic situation of slum dwellers, leading to a vicious cycle whereby poverty leads to slum development and it in turn breeds more poverty (Hari, 2006). Despite, the unsustainable nature of slum communities, some writers, development organisations argue that slums tend to have very complex social relationship, as there is a friendly, intimate and close- knit community, reminiscent of that which exists in small towns and rural areas (Durand-Lasserve, 1996; Jerome, 1990; UNCHS, 2003) The experience of slum-dwellers starkly illustrates that people living in poverty not only face deprivation but are also trapped in poverty because they are excluded from the rest of the society, denied a say, and threatened with violence and insecurity [Amnesty International, 2009]. There is indeed a clean lack of empowerment and social capital and corrupt authorities have taken advantage of this. The residents in these areas live under deplorable conditions with lack of the most basic needs and social amenities and face multi-dimensional challenges which require multi-dimensional interventions such as clean water supply and improved sanitation, energy, solid waste management, housing, schools, and hospitals (United Nations, 2006; Centre on Housing Rights and Evictions, 2008). While the low quality of housing and the general lack of basic infrastructure especially sanitation, drainage, access to energy and clean water supply result in 
poor social and environmental conditions, high levels of unemployment and low income give rise to conflicts (Beatley, 2000; Smith \& Hanson, 2003; Pamoja Trust, 2009). The situation is not helped by lack of supporting policies for effective urban planning and improvement. The main objectives of present paper are,

1. Try to depict out clear picture about the livelihood pattern of slum dwellers and actual condition of slum people.

2. Try to find out the factors behind the formation of slums apart from poverty

3. To know about the entire environmental condition of slum dwellers along with their family planning awareness.

\section{Review of Literature}

Several studies have examined various aspects of slums and come out with diverse findings. Breman (2006) conducted a study on world-historic shift in human habitat. He found that more than half of the global population will soon be city dwellers, in one form or another. The small-scale settlements that have been the cradle of peasant work and life for many thousands of years the myriad villages, compact or dispersed, spread out across the country side are no longer home to the majority of mankind. At present, 3.2 billion people are congregated in towns and cities. Their number is expected to grow to 10 billion in the middle of this century. This gigantic shift is mainly taking place in the zones of the South: within the next two decades, metro poles such as Jakarta, Dhaka, Karachi, Shanghai or Mumbai will each have 25 million inhabitants or more. Akter T (2008) highlights the socio economic condition of slum dwellers and their consumption pattern. The field data of the present study analyze the living conditions, Physical Environment, household's health behaviour particularly dietary practice and health outcomes in Dhaka city. On the basis of access to food and utilization of food, living conditions and the situation of food security of urban poor were analyzed. The study observed that living condition of slum dwellers was considerably poor. Socio-economic status of slum dwellers can be characterized as mainly low income group with inadequate education, also poor physical environment with non-existent solid waste disposal system was very common phenomenon in slum areas. Therefore high prevalence of disease among children's living in slums indicates leading unhealthy environment. In such circumstances to ensure food security of urban poor is a challenge if their socio economic condition remains bleak. The study found that majority of them can't afford nutritious food which was expensive to them, socio economic factors like income, expenditure and education were influencing food security in slums were also found. Asker R, Aslam K.S and Akthar M (1992) The studies observed that living condition of the slum dwellers were poor. The facilities for proper disposal of garbage were limited. The study revealed that about $46 \%$ of rural migrants were unskilled and $18 \%$ were unskilled workers. Lack of lavatories forced the slum dwellers to use the open space around. This tended to create a serious problem of sanitation. The study empirically proved that socio economic factors affecting living conditions of rural migrants. Ali Based on NSSO and Census data Chandrasekhar S (2005) gives a picture of difference in the conditions of slums in India and compared the conditions prevailing in the non slum urban, rural areas and the slums. The study showed that literacy rate in rural areas is higher than the slums in states like Kerala, Goa, and Delhi. But the poorer states like Bihar, Madhyapradesh, Rajasthan, literacy rate in slums was higher than rural areas. In the case of sex ratio, slums is higher than in rural areas. In rural areas availability of electricity is higher than slums. The study reveals that for every monthly per capita consumption expenditure class, the percentage of rural household without access electricity, latrines and water facilities was higher than corresponding households in slums and non-slum urban areas. Thus the study found that slums are similar to rural areas in some aspects and dissimilar in some other aspects. Geetha S and SwaminathanMadhura (1996) in a field study in the slum area of Mumbai revealed that sex wise nutritional status, children aged five and 
below showed that girls have higher prevalence of under nutrition compared to boys. On the basis of weight for age, $60.9 \%$ of boys and $72 \%$ of girls were undernourished. The MAC indicator showed that $19.8 \%$ of boys and $36.8 \%$ of girls were undernourished and another $25.2 \%$ of boys and $33.1 \%$ of girl's were moderately undernourished. Both the indicators show that the incidence of under nutrition was significantly higher among girls than boys. Karn S.K, Shigeo Shikura and Harada Hideki (2003) examined the relationship between living environment and Health Status of Urban communities in Mumbai. The survey covered 1070 households in slums, squatters and Pavement dwellers. The study showed that education level and location of residence have influence on the employment type. Housing conditions differ considerably from pavement dwellers to squatters and slums, overall 33\% houses were flimsy, $39 \%$ semi-permanent type and $28 \%$ cemented buildings. Polluted drinking water, insanitary living conditions, poor personal hygiene and food cleanliness are contributed to water related diseases. The impact of poverty and environmental factors highly pronounced between slums and pavement Dwellers. The study revealed that income, literacy, sanitation and personal hygiene have had impact on the morbidity of the people. The study empirically proved the effect of socio-economic and the environmental factors affecting health status of urban poor. Biplob et al. (2011) stated that slum population has been increasing in Bangladesh over the last three decades along with the growth and expansion of cities and towns. But slum facilities are very much unsatisfactory for them due to lack of proper water supply and sanitation system. As a result, majority of population in Bangladesh suffer from different kinds of water and excreta borne diseases that aggravate in their poverty situations. The level of hyginene knowledge and practice has been found to be significantly low among the korail slum dwellers. the sanitary and water supply condition are improving very slowly in this area. Siddique (2001) attempted to examaine the nature, extent, causes and consequences of migration including reverse migration in Bangladesh, social and economic factors of migration, the inter-temporal poverty scenario covering three episodes before migration, after migration and reverse migration. The results of the survey showed that the migrants, when employed, enjoyed higher income and expenditure levels, better housing. Nevertheless, they suffered from problems of extreme congestion, environmental hazard, deteriorated law and order situation etc. Hossain (2005) studied the socioeconomic aspects of internal migration for low-income group in Sylhet city and looked into the economic and social improvement or degradation of such migrants. According to them, the migrants usually came to Sylhet city with the expectation of better job and higher income which were the main pull factors. The lack of resources and low income in their villages were the push factors for migration. But their present incomes did not differ much from the pre-migration income. Moran et al. (2009) Urbanization is occurring at a rapid pace, especially in low-income countries. Dhaka, Bangladesh, is estimated to grow to 50 million by 2015, with 21 million living in urban slums. This paper describes newborn care practices in urban slums in Dhaka and provides program recommendations. Rashid (2004) served on married adolescent women in a slum in Mirpur, Dhaka and found that 83 percent did not work outside the home. Many cited "husband's disapproval, pardah and family prestige" as the reasons . However, this study also finds that increasing poverty and hunger means that poor married adolescent women are willing to abstain from pardah and cultural restrictions to work outside the home, nearly 10 percent worked in garment factories and 3 percent worked as domestic servants. Many were involved in income generating activities inside their homes such as sewing and embroidery. Gruebner et al, (2011) The survey conducted by the Centre for Urban Studies, which attempted to cover all of Dhaka's slums, reveals something of what life is like in them. Typically, slum houses are just 75-100 square feet in size and consist of a single room. Very high population density, very poor environmental services and very low socioeconomic status were nearly ubiquitous characteristics. Poor drainage, flooding and very poor housing also affected most slums. Lack of electricity, cooking gas, tap water, garbage collection affected a minority of slums, as did insecure tenure, threat of eviction, and a need to share water sources 
and latrines with large numbers of other households. The literature reviewed above shows that no detailed studies were conducted in Bangladesh to address the displacement, deplorable living conditions on slum dwellers in Sylhet city. The present study will help researchers and policy makers for further development of this segment in slum areas of Bangladesh.

\section{Methodology}

The research design of the research is descriptive . Both Quantitative and Qualitative research methods are used. In this paper the whole study has been based on primary data but secondary data also has been used for comparing and validating primary data. Questionnaire Survey is the research techniques. The primary data were collected from 120 slum households of the Loharpara, Ambarkhana Sylhet through a well structured and pre-tested questionnaire and data collected from June 2014 to September 2014. The purposive random sampling technique has been taken for survey work. In this method, random sampling is made from a broad section of the population, considered by the investigator to represent the entire population faithfully with respect to the variable under study. But such a sample may be biased if the assumption about the representative nature does not hold good for the relevant section of the population. Convenience sampling is the sampling procedure of this research. Each adult member of respective slums is a unit of analysis. SPSS is used to analyze the data. Single and Multiple variable analysis are adopted to meet the purpose of the study. 
RESULTS AND DISCUSSION

Table 1. Descriptive Statistics ( Mean and Standard Deviation).

\begin{tabular}{|c|c|c|c|c|c|}
\hline & $\mathrm{N}$ & Minimum & Maximum & Mean & Std. Deviation \\
\hline $\begin{array}{c}\text { Number of Family } \\
\text { Members }\end{array}$ & 120 & 3 & 10 & 4.86 & 1.741 \\
\hline $\begin{array}{c}\text { Number of School } \\
\text { Going Children }\end{array}$ & 120 & 0 & 6 & 1.70 & 1.406 \\
\hline $\begin{array}{c}\text { Number of Bread } \\
\text { Earner of the Family }\end{array}$ & 120 & 1 & 5 & 2.17 & 1.007 \\
\hline $\begin{array}{c}\text { Years Being in Current } \\
\text { Slum }\end{array}$ & 120 & 1 & 15 & 9.33 & 7.490 \\
\hline $\begin{array}{c}\text { Years Since Slum Life } \\
\text { Started }\end{array}$ & 120 & 1 & 35 & 12.41 & 7.275 \\
\hline $\begin{array}{c}\text { Total Width of The } \\
\text { House(SQ Feet) }\end{array}$ & 120 & 15 & 24 & 16.50 & 1.847 \\
\hline $\begin{array}{c}\text { Number of Families } \\
\text { Who Share Same Bath }\end{array}$ & 120 & 3 & 35 & 18.33 & 7.175 \\
\hline $\begin{array}{c}\text { Number of Families } \\
\text { Who Share Same } \\
\text { Toilet }\end{array}$ & 120 & 1 & 10 & 6.88 & 3.919 \\
\hline $\begin{array}{c}\text { Total Monthly Income } \\
\text { of the Family }\end{array}$ & 120 & 3000.00 & 32000.00 & 10083.3333 & 4937.36539 \\
\hline Valid N (list wise) & 120 & & & & \\
\hline
\end{tabular}

Table 2.

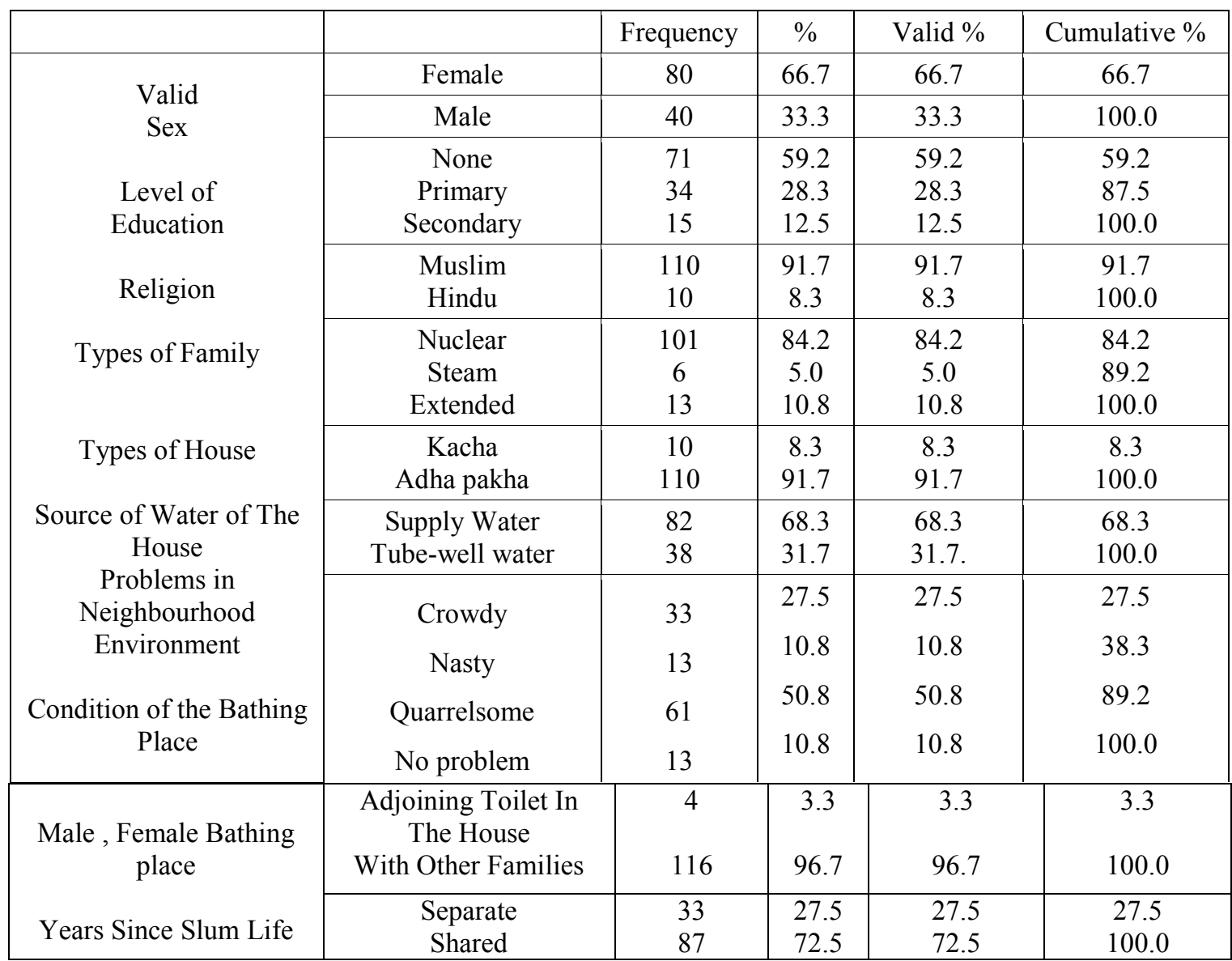




\begin{tabular}{|l|c|c|c|c|c|}
\hline Started & Less than 5 years & 18 & 15.0 & 15.0 & 15.0 \\
& 5 to 10 years & 48 & 40.0 & 40.0 & 55.0 \\
& 10 to 15 years & 22 & 18.3 & 18.3 & 73.3 \\
& 15 to 20 years & 19 & 15.8 & 15.8 & 89.2 \\
& More than 20 years & 13 & 10.8 & 10.8 & 100.0 \\
\hline
\end{tabular}

On the basis of table 2 shows that There are 80 female respondents $(66.7 \%)$ and 40 male respondents $(33.3 \%)$. Here, our most of the respondents are female. There are 71 household heads who have no education $(59.2 \%), 34$ household heads have primary level of education (28.3\%), 15 household heads have Secondary level of education (15.2\%).we find that, most of the household head have no education and rests have very little education. Here 110 respondents are muslim $(91.7 \%)$ and 10 respondents are hindu $(8.3 \%)$ and 101 families are nuclear $(84.2 \%), 6$ are steam $(5.0 \%)$ and 13 families are extended $(10.8 \%)$. We find that, 10 of the houses are kacha (8.3\%)and 110 of the houses are adha paka (91.7\%).6 In our analysis we locate that, 82 households use supply water $(68.3 \%)$ and 38 households use tubewell water $(31.7 \%)$. In stating about problems in their neighbourhood environment, 33 of the respondents said that it is crowdy $(27.5 \%), 13$ said that it is nasty $(10.8 \%), 61$ said that it is quarrelsome $(50.8 \%)$, and 13 said that there is no problem in their neighbourhood environment. 4 households use bathing place as Adjoining toilet of the house (3.3\%), 116 households share bathing place with other families $(96.7 \%)$. On the other hand 33 families use separate bathing place (27.5\%) and 87 families use shared bathing place $(72.5 \%)$ for male and female. At this point 18 respondents have been living in slum for less than five years $(15.0 \%), 48$ respondents for five to ten years $(40.0 \%), 22$ respondents for ten to fifteen years $(18.3 \%), 19$ respondents for fifteen to twenty years $(15.8 \%)$, and 13 respondents for more than twenty years $(10.8 \%)$.

Table 3.

\begin{tabular}{|c|c|c|c|c|c|}
\hline \multirow{4}{*}{ Valid } & & Frequency & $\%$ & Valid \% & $\begin{array}{c}\text { Cumulative } \\
\%\end{array}$ \\
\hline \multirow{4}{*}{ Family Planning Awareness } & & & & & \\
& Aware & 40 & 33.3 & 33.3 & 33.3 \\
\cline { 2 - 6 } & Moderately aware & 67 & 55.8 & 55.8 & 89.2 \\
\cline { 2 - 6 } & Not aware & 13 & 10.8 & 10.8 & 100.0 \\
\cline { 2 - 6 } Family Planning Method Used & Tubectomy or NSV & 11 & 9.2 & 9.2 & 9.2 \\
\cline { 2 - 6 } & Ligation & 11 & 9.2 & 9.2 & 18.3 \\
Family Planning Workers Visit In & Injection & 6 & 5.0 & 5.0 & 23.3 \\
The House & Pill & 44 & 36.7 & 36.7 & 60.0 \\
\cline { 2 - 6 } & Don't use any method & 36 & 30.0 & 10.0 & 70.0 \\
\cline { 2 - 6 } & Yes & 101 & 84.2 & 84.2 & 84.2 \\
& No & 19 & 15.8 & 15.8 & 100.0 \\
\hline
\end{tabular}

In table 3, we find that, 40 respondents are aware (33.3\%), 67 are moderately aware $(55.8 \%)$, and 13 are not aware $(10.8 \%)$ of family planning. Of this table, 11 of the respondents $(9.2 \%)$ used Tubestomy or NSV, 11 of the respondents (9.2\%) used Ligation, 6 of the respondents $(5.0 \%)$ take Injection, 44 of the respondent $(36.7 \%)$ take pill, 12 of the respondents use 
condom $(10 \%), 36 \%$ of the respondents don't use any method. In this analysis 101 respondents $(84.2 \%)$ said that family planning workers visit their house and 19 respondents $(15.8 \%)$ said that not

Table 4.

\begin{tabular}{|c|c|c|c|c|c|}
\hline & & Frequency & $\%$ & Valid \% & Cumulative \% \\
\hline \multirow{3}{*}{$\begin{array}{c}\text { Types of Diseases Those Suffered } \\
\text { Last Six Months }\end{array}$} & Diarrhoea & 17 & 14.2 & 14.2 & 14.2 \\
\hline & Dysentery & 13 & 10.8 & 10.8 & 25.0 \\
\hline & Others & 90 & 75.0 & 75.0 & 100.0 \\
\hline $\begin{array}{c}\text { General Tendency of Taking } \\
\text { Treatment }\end{array}$ & $\begin{array}{c}\text { Hospital } \\
\text { Community Clinic } \\
\text { Kobiraj } \\
\text { Both hospital and } \\
\text { Kobiraj }\end{array}$ & $\begin{array}{c}71 \\
22 \\
2 \\
25\end{array}$ & $\begin{array}{c}59.2 \\
18.3 \\
1.7 \\
20.4\end{array}$ & $\begin{array}{c}59.2 \\
18.3 \\
1.7 \\
20.8\end{array}$ & $\begin{array}{c}59.2 \\
77.5 \\
79.2 \\
100.0\end{array}$ \\
\hline Drainage System Beside The House & $\begin{array}{c}\text { Kacha Drain } \\
\text { Pacca Drain } \\
\text { Others } \\
\text { No Drainage system }\end{array}$ & $\begin{array}{l}13 \\
77 \\
14 \\
16\end{array}$ & $\begin{array}{l}10.8 \\
64.2 \\
11.7 \\
13.3\end{array}$ & $\begin{array}{l}10.8 \\
64.2 \\
11.7 \\
13.3\end{array}$ & $\begin{array}{c}10.4 \\
75.0 \\
86.7 \\
100.0\end{array}$ \\
\hline \multirow[t]{2}{*}{ Household } & $\begin{array}{c}\text { Dustbin } \\
\text { City Corporation Van } \\
\text { Back of the Toilet } \\
\text { Nearer Drain }\end{array}$ & $\begin{array}{l}35 \\
46 \\
24 \\
15\end{array}$ & $\begin{array}{l}29.2 \\
38.3 \\
20.0 \\
12.5\end{array}$ & $\begin{array}{l}29.2 \\
38.3 \\
20.0 \\
12.5\end{array}$ & $\begin{array}{c}29.2 \\
67.5 \\
87.5 \\
100.0\end{array}$ \\
\hline & $\begin{array}{l}\text { Yes } \\
\text { No }\end{array}$ & $\begin{array}{l}41 \\
49\end{array}$ & $\begin{array}{l}34.2 \\
65.8\end{array}$ & $\begin{array}{l}34.2 \\
65.8\end{array}$ & $\begin{array}{c}34.2 \\
100.0\end{array}$ \\
\hline
\end{tabular}

In table 4, the study revealed 17 families suffered from Diarrhoea(14.2\%), 13 families suffered from Dysentery(10.8\%), and 90 families suffered from other diseases in last six months. Here 71 families go to hospital (59.2\%), 22 families go to community clinic (18.3\%), 2 families go to kabiraj (1.7\%), and 25 families go to both hospital and kabiraj $(20.8 \%)$, On the other hand there is kacha drain besides 13 houses $(10.8 \%)$, pacca drain besides 77 houses $(64.2 \%)$, others besides 14 houses $(11.7 \%)$, and no drainage system besides 16 houses (13.3\%). 35 families use dustbin (29.2\%), 46 families use city corporation van (38.3\%), 24 families use back of the toilet (20.0\%), and 15 families use nearer drain $(12.5 \%)$ for their garbage disposal.Finally we can see that, 41 houses were inundated $(34.2 \%)$ and 79 houses were not .

\section{CONCLUSION}

The rapid growth of population in urban centres since independence has led to the emergence and growth of urban slums in the country. They have been contributing significantly to the economy of any city by providing affordable labour for formal as well informal sectors of the economy. There is no denying fact that slums have become an integral part of urbanisation and in a way manifestation of overall socio-economic policies and planning in the country. According to the study, climate induced displacement added into 
urban migration is very alarming for city dwellers as it creates increasing pressure on existing system and challenges to government. Slum improvement not only uplifts living quality of urban poor but also supports adaptation measure of climate change, while planned migration of climate induced displaced is a present day concern. Deplorable living condition of slum dwellers can be characterized as mainly low income group with inadequate education, in the absence of proper shelter were settled in pockets of the slum areas regarded as by overcrowding, dilapidated dwellings, lack of sanitation and civic amenities, high prevalence of disease among inhabitants living in slums indicates leading unhealthy environment. In such circumstance, to ensure food security of urban poor is a challenge if their deplorable condition remains miserable. Urban congestion, high unemployment rate and above all it new streams of immigrants coming in these settlements aggregate the problem. There are many problems that challenge the respondent's current living conditions malnutrition, poor sanitation, disability, lack of capital, poverty ,unemployment and health problem. We also found that, most of the families of these slums are poor and have little or no education, entire environment of these slums is nasty and crowdy, Population density is very high, House is either Kacha (poor) or Aadha Paka (Satisfactory). Their family members share same room and room size is also very small. Several families use same bath and toilet. In most cases, there is no separate bathing place for male and female. Toilets are dirty and unhygienic. Now, the system of City Corporation is improved enough and that's why, slum drainage system and garbage disposal system is improved, but in some cases it remains bad. We also have come to know that most of the respondents are moderately aware of family planning. But this is not the result of the education level of the head of the family and not the result of their total family income. We found that, family planning workers visit their house and literate or illiterate all are now moderately conscious about family planning. So, family planning workers visit is an important factor of family planning awareness among slum people. But many of them fell doubt that whether this method is against to their religion. To conclude, we can say that a big number of people, known as slum dweller, are forced to live below poverty line. The main reason of their poverty is illiteracy and lack of will power to improve his condition. They always look for the government helps; debt, relief etc. and wait for them, this type of mentality and government plans make them paralyzed instead of self reliance. They lack behind good education, health, sanitation and economy. There is need to focus their problems and a strong heart and mind to execute these programmes. If it happens so, the day will come with hope for them and for the people who are affected by these slum dwellers. . Finally, our result suggests that, entire conditions of urban slums should be improved and religious barriers should be overcome for effective family planning. If the government, civil society NGO and other stakeholders give priority and work seriously, then the slum dweller will be benefitted in a greater extent . 


\section{References}

[1] Mutisya E., Yarime M., Understanding the Grassroots Dynamics of Slums in Nairobi: The Dilemma of Kibera Informal Settlements . International Transaction Journal of Engineering, Management, \& Applied Sciences \& Technologies, 2 (2011)197-213.

[2] Sandip M T., Assessment Of Socioeconomic Status Of Marginalized Semi-Urban Slum Dwellers On The Basis Of Attainment Of Education: A Case Study In Patharghata Slum, Ballavpur Mouza, Midnapur District, West Bengal . Journal of Business Management \& Social Sciences Research (JBM\&SSR), 2(2013) 56-61 .

[3] Verma et al.,"A Study of Male Sexual Health Problems in a Mumbai Slum Population” Culture Health and Sexuality, 3(2001).

[4] Nijama N., Urban Malaria: Primary Caregivers' Knowledge Attitude Practices and Predictors of Malaria Incidence in a Cohort of Ugandian Children, Tropical Medicine and International Health, 8 (2003)

[5] R Prasad R., Singh M N., Living conditionn and life style of Mankhurd slum dwellers. International Institute for Population Sciences, Mumbai.

[6] Sufaira C., Socio Economic Conditions of Urban Slum Dwellers in Kannur Municipality. IOSR Journal Of Humanities And Social Science (IOSR-JHSS), 10(May. - Jun. 2013)1224.

[7] Tripathy S., Socio- Economic Status of Marginalised Semi- Urban Slum Dwellers of Ballavpur Mouza, Midnapur District, West Bengal . International Journal of Current Research ,5 (2013) 630-633.

[8] Phillip S R., Premsingh G J., A Study on the Socio-Economic Condition of slum Dwellers with special Reference to Calicut Corporotion. IJSR - International journal of scientific research, 3 (2014)392-394.

[9] Hossain K Z., Ahmed S A., Non-conventional public-private partnerships for water supply to urban slums. Urban Water Journal, Taylor \& Francis, (2014) 1-11.

[10] Amoako C,. Slum Improvement in the Kumasi Umasi Metropolis, Ghana - A Review of Approaches and Results. Journal of Sustainable Development in Africa , 13(2011)150170 .

[11] Sajjad H., Living standards and health problems of lesser fortunate slum dwellers: Evidence from an Indian city. International Journal of Environmental Protection and Policy, 2(2014)54-63.

[12]Pawar D H., Mane V D., Socio-Economic status of Slum Dwellers With Special Reference to Women : Geographical Investigation of Kolhapur slum. Research Front, 1(2013)69-72.

[13]Kothari C R., Research Methodology : Methods and Techniques. Wishwa Prakashan, (2003).

[14]Bagheri M., The Challenge of Slums: Socio-Economic Disparities.

[15] International Journal of Social Science and Humanity, 2(2012)410-414.

[16] Alamgir, M. S., Jabbar, M. A., Islam, M. S., Assessing the livelihood of slum ewellers in Dhaka city. Journal of Bangladesh Agril. Univ, 7(2009) 373-381. 
[17]Hossain M A., Moniruzzam M., and Islam M A.,.Urban Environmental Health in Bangladesh Slum :A Comparative study of Two Metropolitan . J. Sci. Foundation, 8(1\&2) (2010) 67-76.

[18]Hossain S., Rapid Mass Urbanisation and Its Social Consequences in Bangladesh: The Case of the Megacity of Dhaka. This paper was presented to the 16th Biennial Conference of the Asian Studies Association of Australia in Wollongong, 2-9(26 June 29 June 2006)

[19]Begum A., Destination Dhaka Urban Migration : Expectations and Reality. The University Press Limited, 27-63 (1999). 